UNIVERSITAS MUHAMMADIYAH MALANG JP2SD (JURNAL PEMIKIRAN

DAN PENGEMBANGAN SEKOLAH DASAR)

http://ejournal.umm.ac.id/index.php/jp2sd

p-ISSN: 2338-1140 e-ISSN: 2527-3043

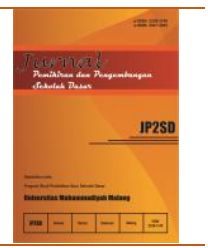

\title{
Aplikasi Si Marbel Sebagai Alternatif Media Pembelajaran Tematik di Pendidikan Dasar
}

\author{
Siti Mukaromah ${ }^{\text {a1 }}$, Khusna Widhyahrini ${ }^{\text {a2}}$, Norwanto ${ }^{\text {b3 }}$ \\ apascasarjana PGMI IAIN Salatiga, Indonesia \\ ${ }^{b}$ FTIK, IAIN Salatiga, Indonesia \\ 1sitimukaromah73@gmail.com
}

\begin{tabular}{ll}
\hline INFORMASI ARTIKEL \\
\hline Riwayat: & \\
Diterima & 23 Juli 2020 \\
Revisi & 9 Agustus \\
& 2020 \\
Dipublikasikan & 21 September \\
& 2020
\end{tabular}

Kata kunci:

aplikasi permainan, media pembelajaran, permainan edukatif

\begin{abstract}
ABSTRAK
Penelitian ini bertujuan untuk melakukan analisis kebutuhan untuk mengembangkan aplikasi permainan edukatif $\mathrm{Si}$ Marbel sebagai media pembelajaran tematik di kelas 1 Sekolah Dasar (SD); mengembangkan dan menguji penerapan aplikasi pendidikan Si Marbel sebagai media pembelajaran tematik di kelas 1; dan mengetahui efektivitas aplikasi permainan edukatif $S i$ Marbel sebagai media pembelajaran tematik di kelas 1 SD. Penelitian ini menggunakan metode pengembangan atau Research and Development (R\&D) dan aplikasi Si Marbel adalah produk penelitian ini. Model penelitian yang digunakan adalah model desain instruksional ADDIE (Analysis-DesignDevelop-Implement-Evaluate).. Hasil dari penelitian ini adalah berupa pengembangan aplikasi permainan edukatif Si Marbel. Hasil penilaian pakar media masing-masing adalah 90 dan 93. Rata-rata adalah 91,5 yang menunjukkan bahwa pengembangan aplikasi pendidikan Si Marbel valid dan dapat diterapkan untuk pembelajaran di kelas $1 \mathrm{MI}$ Negeri Salatiga. (3) Uji efektifitas menunjukkan signifikansi (2-tailed) adalah $0.000(\mathrm{p}<0,05)$. Hasil pretest dan post-test menunjukkan perubahan yang signifikan. Statistik deskriptif dari nilai-nilai pre-test dan post-test menunjukkan bahwa skor post-test lebih baik. Oleh karena itu, aplikasi permainan edukatif Si Marbel terbukti efektif digunakan dalam pembelajaran tematik tema 5 "Pengalamanku".
\end{abstract}

\section{ABSTRACT}

Keywords:

application, learning media, educational games, primary school
This study aims to do need analysis, to develop, and to test the applicability and the effectiveness of Si Marbel, an educational application as a thematic learning media in $1^{\text {st }}$ level of primary school. Study was Research and Development (R\&D) applying ADDIE (Analysis-DesignDevelop-Implement-Evaluate). Si Marbel was the research 


\begin{tabular}{|c|c|}
\hline 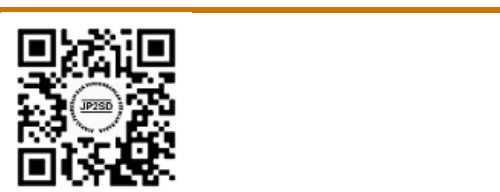 & $\begin{array}{l}\text { and 93. They indicates that Si Marbel was valid to be } \\
\text { implemented in the thematic class of "my experiences" of } \\
1^{\text {st }} \text { level of MIN (State Islamic Elementary School) Salatiga. }\end{array}$ \\
\hline $\begin{array}{l}\text { Copyright }{ }^{\circ} 2020, \\
\text { Mukaromah, Siti } \\
\text { Widhyahrini, Norwanto }\end{array}$ & $\begin{array}{l}\text { The effectivity test of the class showed that the significance } \\
(2 \text {-tailed) was } 0.000(\mathrm{p}<0.05) \text {. The pre-test and post-test } \\
\text { results indicated significant changes on students' learning }\end{array}$ \\
\hline $\begin{array}{l}\text { This is an open ace } \\
\text { under the CC-BY-S }\end{array}$ & $\begin{array}{l}\text { means there are differences in learning outcomes before and } \\
\text { after using the educational game application Si Marbel. It } \\
\text { can be concluded that Si Marbel is effective for teaching } \\
\text { "Mv Experience" thematic subiect classes. }\end{array}$ \\
\hline \multicolumn{2}{|c|}{$\begin{array}{l}\text { How to cite: Siti Mukaromah, Khusna Widhyahrini, Norwanto. (2020). Aplikasi Si Marbel } \\
\text { Sebagai Alternatif Media Pembelajaran Tematik di Pendidikan Dasar. Jurnal Pemikiran dan } \\
\text { Pengembangan Sekolah Dasar, Vol } 8 \text { No 2, 138-147. doi: 10.22219/jp2sd.v8i2.13005 }\end{array}$} \\
\hline
\end{tabular}

\section{PENDAHULUAN}

Pendidikan adalah usaha sadar dan terencana untuk mewujudkan suasana belajar dan proses pembelajaran agar peserta didik secara aktif mengembangkan kemampuan (Unver, 2018). Perkembangan ilmu pengetahuan dan pembelajaran saat ini telah membawa perubahan, sesuai dengan hakekat kurikulum itu sendiri. Kurikulum merupakan seperangkat rencana dan pengaturan mengenai tujuan, isi, dan bahan pembelajaran untuk mencapai tujuan pendidikan secara khusus (Undang-Undang Sistem Pendidikan Nasional No.20 Tahun 2003).

Tujuan pendidikan nasional menurut Undang-Undang Sistem Pendidikan Nasional No.20 Tahun 2003 adalah untuk mengembangkan kemampuan peserta didik agar menjadi manusia yang memiliki sikap bermakna. Pendidikan diharapkan selain menumbuhkembangkan pengetahuan peserta didik juga meningkatkan sikap dan ketrampilannya. Kurikulum 2013 dengan pembelajaran tematik merupakan pembelajaran yang terintegrasi semua mata pelajaran dapat mencapai kompetensi sikap, pengetahuan, dan keterampilan dalam semua proses pembelajaran. Pembelajaran tematik adalah gabungan dari beberapa mata pelajaran dalam satu tema yang terdiri dari beberapa sub tema, sehingga pendidik harus mampu mengemas keseluruhan materi pembelajaran dalam satu kemasan yang menarik.

Wawancara dengan kepala madrasah dan guru kelas 1 di Madrasah Ibtidaiyyah Negeri (MIN) Salatiga menunjukkan bahwa pembelajaran di kelas satu masih menggunakan media yang sederhana, seperti kartu kata dengan tulisan tangan dan beberapa kartu kata yang yang ditempel di dinding. Metode yang sering digunakan adalah ceramah dan pemberian tugas. Hal ini berpengaruh terhadap pelaksanaan pembelajaran di kelas dan berdampak pada hasil belajar. Upaya yang dapat dilakukan epala madrasah untuk meningkatkan mutu guru dengan memberi motivasi, karena guru profesional harus bisa memenuhi empat kompetensi yang telah ditetapkan dalam undangundang No. 14 tahun 2015 tentang guru dan dosen (Nugraheni \& Siti Khanifah, 2016). Pendidik jarang menggunakan alat peraga edukatif (APE) berbasis teknologi seperti aplikasi permainan berbasis Android yang menarik untuk memenuhi tuntutan perkembangan zaman (Muazzomi, 2017). Kendala yang dihadapi karena biaya pengadaan serta keterbatasan kemampuan dalam membuatnya. Lembaga pendidikan 
diyakini sebagai tumpuan yang mampu mengembangkan SDM yang memililiki keutuhan kepribadian dan menguasai ilmu pengetahuan dan tehnologi, karena globalisasi dipacu dengan Iptek dan pendidikan adalah sumber pengembangan Ilmu Pengetahuan dan Teknologi (Suparlan, 2014).

Permainan bagi anak sangatlah penting, bermain dan belajar adalah dua hal yang berbeda, tapi sangat dekat bagi mereka. Di ajaran Islam, bermainpun diperbolehkan dan diperlukan untuk mendapatkan kesenangan. Akan tetapi Islam juga memberikan petunjuk, permainan tidak boleh menyia-nyiakan waktu (Astini et al., 2016).

Tuntunan tersebut terdapat dalam firman Allah dalam al Quran surat Al Jumuah ayat 11 yang menjelaskan perlunya permainan dalam proses pembelajaran. Permainan memberi kesempatan pada anak untuk belajar bersaing dengan sehat dan mampu mengembangkan social skill, motoric skill, dan emotional skill pada permainan yang bersifat kompetisi, bahwasanya permainan tradisional memiliki karakteristik selain mendahulukan faktor kegembiraan bersama, juga memiliki maksud pada pendalaman kemampuan interaksi antar pemain (potensi interpersonal) (Astini et al., 2017; Wijayanti, 2014).

Berdasarkan uraian latar belakang, maka peneliti akan melakukan penelitian dengan judul "Pengembangan Aplikasi Permainan Edukatif Si Marbel Sebagai Media Pembelajaran Tematik" pada peserta didik Kelas I MI N Salatiga Tahun Pelajaran 2019/2020. Pengembangan media pembelajaran ini diharapkan mampu membantu peserta didik kelas 1 lebih cepat memahami pelajaran tematik.

Berdasarkan kekurangan yang menjadi dasar proses pembelajaran, hal yang mendasar perlu dikaji adalah mengenai kebutuhan pengembangan aplikasi permainan edukatif $\mathrm{Si}$ Marbel sebagai media pembelajaran tematik, pengembangan aplikasi permainan edukatif Si Marbel sebagai media pembelajaran tematik, serta seberapa besar efektifitas pengembangan aplikasi permainan edukatif Si Marbel sebagai media pembelajaran tematik.

Oleh karena itu, penelitian ini bertujuan untuk melakukan analisis kebutuhan untuk mengembangkan aplikasi permainan edukatif $S i$ Marbel sebagai media pembelajaran tematik di kelas 1, mengembangkan dan menguji penerapan aplikasi pendidikan Si Marbel sebagai media pembelajaran tematik di kelas 1, sertaengetahui efektivitas aplikasi permainan edukatif Si Marbel sebagai media pembelajaran tematik di kelas 1. Pengembangan aplikasi permainan edukatif Si Marbel ini menjadi kunci kebaruan dari penelitian ini dan menjadi suatu instrumentasi untuk melihat keberhasilan proses pembelajaranmasyarakat.

\section{METODE}

Penelitian ini menggunakan model ADDIE (Analysis, Desain, Development, Implementation, and Evaluation). Pengembangan produk aplikasi permainan edukatif $S i$ Marbel meliputi langkah-langkah (1) mengembangkan aplikasi permaian edukatif melalui media komputer, (2) pembimbingan dengan validator, (3) validasi dari ahli media (4) validasi dari ahli materi. Penerapan pengembangan aplikasi permainan edukatif $S i$ Marbel pada peserta didik kelas I MI Negeri Kota Salatiga, dengan menggunakan pre experimental reseach.

Analisis dilakukan untuk mengumpulkan informasi sebelum penelitian dilakukan dengan cara studi lapangan dan studi pustaka. Studi lapangan digunakan untuk menganalisis pengembangan materi tematik kelas I. Studi pustaka digunakan untuk menganalisis kebutuhan secara mendalam guna menemukan literatur penelitian yang relevan. Desain yang dikembangkan oleh peneliti yaitu menyusun media pembelajaran 
berbentuk apliakasi permainan edukatif Si Marbel untuk materi pelajaran bahasa Indonesia kelas I MI

Langkah-langkah pengembangan model ADDIE pada penelitian ini dijelaskan dalam skema pada Gambar 1.

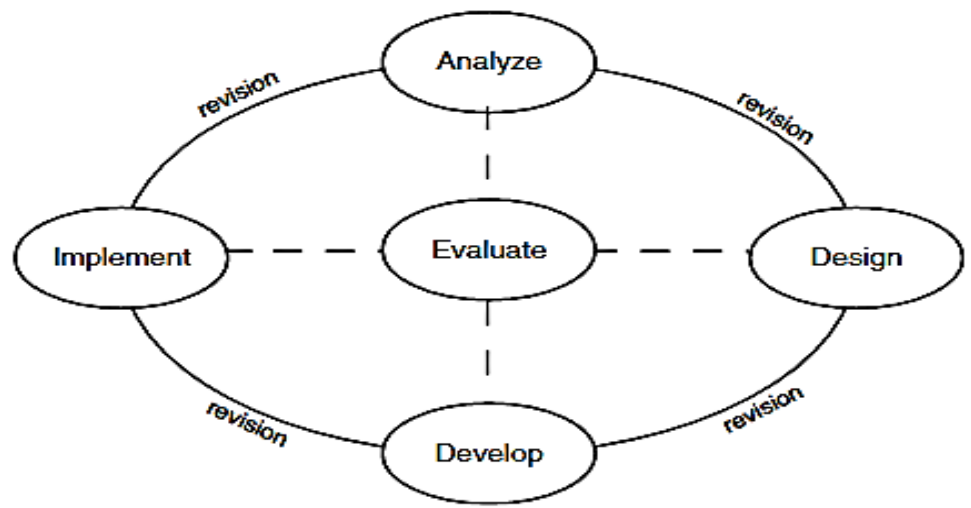

Gambar 1. Bagan model ADDIE (Branch, 2009)

Evaluasi dilakukan untuk mengetahui dan mengukur apakah media yang dikembangkan layak digunakan. Uji kelayakan dilakukan oleh ahli dengan mengisi kuesioner kelayakan produk yaitu aplikasi permainan edukatif Si Marbel. Setelah aplikasi dinyatakan layak, kemudian aplikasi diimplementasikan didalam pembelajaran tematik di kelas 1 MI Negeri Salatiga. Aplikasi setelah diterapkan diadakan evaluasi dengan post-test melalui online kepada peserta didik.data (Huberman, 2017).

\section{HASIL DAN PEMBAHASAN}

Wawancara dengan kepala madrasah dan guru kelas 1 di Madrasah Ibtidaiyyah Negeri (MIN) Salatiga menunjukkan bahwa pembelajaran di kelas satu masih menggunakan media yang sederhana, seperti kartu kata dengan tulisan tangan dan beberapa kartu kata yang yang ditempel di dinding. Metode yang sering digunakan adalah ceramah dan pemberian tugas. Hal ini berpengaruh terhadap pelaksanaan pembelajaran di kelasdan berdampak pada hasil belajar.

Pendidik jarang menggunakan alat peraga edukatif (APE) berbasis teknologi seperti aplikasi permainan berbasis android yang menarik untuk memenuhi tuntutan perkembangan zaman. Kendala yang dihadapi karena biaya pengadaan serta keterbatasan kemampuan dalam membuatnya.

Hasil wawancara dengan Ibu Mustafifah, pendidik kelas 1A adalah pendidik menghadapi kesulitan yang berbeda berdasarkan tema pembelajaran, setiap tema memiliki tingkat kesulitan yang berbeda baik dari dari segi alat peraga maupun kemampuan peserta didik. Mustafifah, pendidik kelas 1A, mengungkapkan bahwa kompleksitas pengajaran SBdP (Seni Budaya dan Prakarya) terletak pada penyiapan media pembelajaran. Dia menyebut bahan media "agak riwil". Dalam konteks setempat, "riwil" artinya bermacam-macam. Guru dapat meminta bantuan orang tua dalam menghadapi kesulitan yang dihadapi oleh peserta didik. "Kerja sama dengan orang tua lewat group menggunakan aplikasi WhatsApp untuk menyiapkan bantuan bahan dari rumah".

Hasil wawancara dengan Ibu Patmi, pendidik kelas 1B, kesulitan yang dihadapi waktu mengajar tematik adalah pada tema 1 anak-anak belum mengetahui nama bapak dan ibunya, pada tema ke-5, pengalaman anak-anak bermacam-macam, kemampuan menyampaikan pengalamannya juga bermacam-macam, ada yang pandai menyampaikan 
dan ada yang masih malu-malu. Kesulitan lainnya adalah anak-anak belum pandai menulis dan di lingkungan TK tidak dituntut untuk pandai membaca dan menulis. Solusi yang diambil oleh Patmi pada tema Pengalamanku yaitu dengan alat gambar, melihat gambar-gambar di kelas ataupun gambar-gambar di buku, dan membantu anak berlatih mengungkapkan pengalamannya waktu di TK.

Wawancara dengan Ibu Rani, pendidik kelas 1C, didapatkan informasi kesulitan yang dihadapi dalam mengajar tematik adalah pada tema pengalamanku karena banyak anak-anak yang agak kesulitan dalam percakapan, ada beberapa peserta didik yang belum bisa membaca, memperagakan dan menyampaikan ungkapan dan ajakan, terima kasih. Solusi yang diambil Rani adalah dengan membuat kartu, kartu bergilir kartu undian atau apa, bermain peran, bermain tebak-tebakan siapa yang bisa jawab, dikasih kesempatan memainkan peran, dikasih nama si A, si B, si C, mereka bergantian, mereka juga perform. Akan tetapi media dan metode itu masih kurang efektif, kalau mau membuat yang lebih interaktif, pendidik-pendidik belum bisa membuatnya.

Hasil wawancara dengan Ibu Tutik, pendidik yang pernah mengampu kelas 1, juga menghadapi kesulitan saat mengajarkan tema di kelas I pada semester 2 adalah tema pengalamanku, anak-anak masih sulit mengungkapkan sesuatu, kalau di TK ada brand storming, ungkapan anak kita tulis di papan tulis. Kesulitan lainnya adalah mengungkapkan pujian terhadap pekerjaan teman, pendidik perlu mepancing dengan brand storming. Solusi yang dilakukan Tutik adalah memakai gambar-gambar untuk memancing anak-anak dalam mengungkapkan dan memuji dengan gambar.

Kesulitan senada juga didapat dari hasil wawancara dengan Ibu Sanah, pernah mengampu kelas 1 pada waktu mengajar di kelas I adalah pada tema pengalamanku, karena materi "mengungkapkan" agak susah. Solusi yang diambil Sanah adalah dengan gambar-gambar untuk membantu anak-anak. Karena pada gambar itu ada contoh, sehingga memancing anak untuk bisa mengungkapkan.

Berdasarkan analisis hasil wawancara dengan pendidik kelas 1-A, B, C, dan pendidik yang pernah mengampu kelas 1, maka dapat disimpulkan bahwa semua pendidik mengalami kesulitan di dalam mengajar tematik kelas 1. Adapun kesulitannya berbedabeda ada yang mengalami kesulitan pada penyampaian materi, ada yang pada karakter anak, ada juga yang pada keterbatasan media. Semua pendidik menyambut baik jika diperkenalkan dengan aplikasi permainan edukatif untuk digunakan dalam pembelajaran. Pembelajaran di kelas efektifnya memmerlukan dukungan yang memadai terhadap halhal yang terkait dengan pembahasan (Panigrahi, 2014).

Oleh karena itu aplikasi pembelajaran diperlukan untuk memberikan solusi dalam penyampaian materi yang menjadi kesulitan pendidik. Kesulitan yang harus diberi solusi padamateri kelas 1, pada materi tema pengalamanku, dari kebutuhan tersebut peneliti membuat aplikasi pembelajaran dengan permainan yakni Si Marbel (Aplikasi Mari Belajar) tema pengalamanku, adapun dalam materi aplikasi tersebut dikategorikan dalam lima kelompok materi permainan, yakni bahasa, matematika, pendidikan kewarganegaraan (PKn), seni budaya dan prakarya (SBdP) serta evaluasi dalam apliaksi yang mencakup empat aspek materi tersebut. Harapan pada akhir pembelajaran, peserta didik menemukan kegiatan yang menyenangkan, menarik dan diminati sehingga menarik minat belajar peserta didik dan kemudian memperoleh pengetahuan secara maksimal. Model pembelajaran harus diperhatikan pendidik, karena model pembelajaran merupakan kerangka konseptual yang dapat dijadikan sebagai pedoman dan penyusunan rencana pembelajaran (Eddia Copeland Solas, 2017; Pétervári et al., 2016). 


\section{Aplikasi Si Marbel}

Aplikasi Si Marbel memiliki sejumlah delapan bagian yaitu cover, daftar materi pembelajaran, muatan bahasa Indonesia, Matematika, PPKn, SBdP, evaluasi pembelajaran, dan sertifikat.

\section{a. Cover}

Cover adalah tampilan awal ketika Si Marbel dibuka. Bagian Cover terdiri dari aplikasi beserta singkatannya, tema dan tanda panah. Untuk melanjutkan ke halaman berikutnya, guru atau peserta didik hsrus klik tombol panah.

b. Menu

Menu terdiri dari tombol (home dan silang) dan materi ajar tema 5 "Pengalamanku" yang terdiri dari "Kalimat Pujian, Bilangan Cacah, Pancasila, Elemen Musik, dan Evaluasi". Tombol "home" untuk melihat seluruh isi. Sedangkan tombol "silang" untuk berhenti menggunakan aplikasi. Berkaitan dengan materi, sub tema didesain dengan gambar pulau dan nama pulau. Untuk masuk ke materi, pendidik atau peserta didik harus klik masing-masing gambar. Untuk keluar dari aplikasi pendidik dan peserta didik dengan cara klik tanda silang. Untuk kembali ke materi awal dengan cara klik tanda home.

\section{c. Materi Pembelajaran Tematik}

Materi pembelajaran tematik yang dipelajari menggunakan aplikasi permainan edukatif Si Marbel ini diambil dari buku Bupena yang diterbitkan oleh PT Erlangga jilid 1C tema 5 "Pengalamanku". Materi pembelajaran langsung dimasukkan ke aplikasi, pendidik menjelaskan materi pembelajaran dari aplikasi tersebut.

\section{d. Evaluasi Pembelajaran}

Evaluasi pembelajaran dilaksanakan setelah akhir pembelajaran, evaluasi dilakukan melalui aplikasi. Evaluasi dalam aplikasi bersifat sebagai latihan, sedangkan untuk penilaian akhir menggunakan ulangan online melalui link google form.

\section{e. Reward}

Reward diberikan kepada peserta didik yang nilainya mencapai KKM (Kriteria Ketuntasan Minimal) pelajaran yang dibuat oleh guru, pada awal tahun pelajaran. KKM pada aplikasi muncul secara otomatis dan sertifikat akan didapatkan oleh peserta didik setelah menyelesaikan pembelajaran. Penggambaran aplikasi Si Marbel ini dapat dilihat pada Gambar 1.

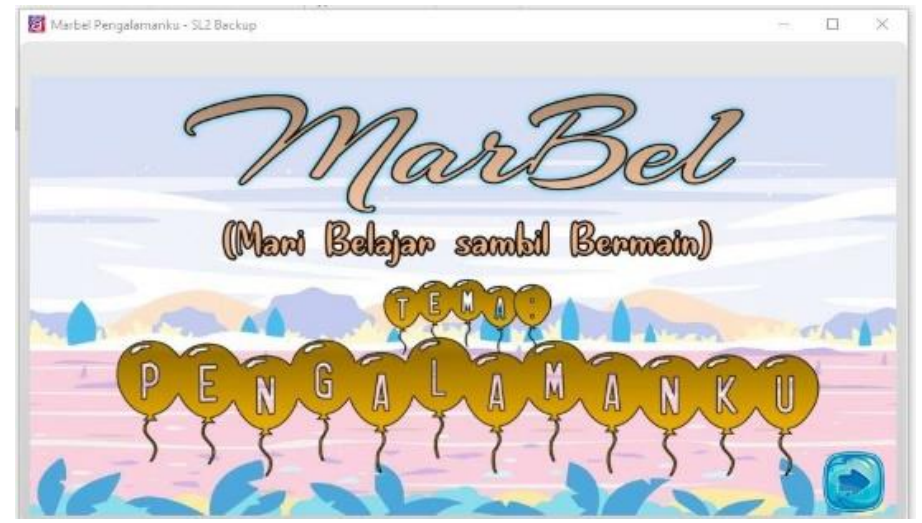

\section{Uji Validitas dan Reabilitas}

Gambar 1. Bagian depan Aplikasi Belajar Si Marbel

Berdasarkan tabel uji validitas soal pretes dan postes dapat dilihat pada kolom koefisien corrected item to total correlation $\geq 0,20$, artinya soal dinyatakan valid, dan selanjutnya dapat digunakan untuk melakukan penelitian. Uji reliabilitas digunakan untuk mengetahui apakah instrumen dapat dipercaya atau tidak dalam penggunaan dalam 
penelitian. Berdasarkan uji reliabilitas terhadap soal yang berjumlah 20 butir yang terdiri dari soal pilihan ganda, pada cronbach's alpha based on standardized items memiliki nilai 0,913 , sehingga dinyatakan reliabilitas soal adalah sangat reliabel.

\section{Uji Efektivitas Penggunaan Aplikasi}

Hasil rata-rata pretest sebelum diberikan treatmen pembelajaran menggunakan aplikasi permainan edukatif Si Marbel adalah 72,50. Nilai rata-rata posttest setelah diberikan treatmen pembelajaran menggunakan aplikasi permainan edukatif Si Marbel adalah 92,19 artinya setelah diberi pembelajaran menggunakan aplikasi permainan edukatif Si Marbel mencapai hasil belajar yang tinggi. Pembelajaran menggunakan aplikasi dapat dijadikan alternative dalam pembelajaran daring agar lebih menyenangkan karena bersifat interaktif (Kuncahyono \& Sudarmiatin, 2018).

\section{Analisis Uji $t$}

Analisis $t$-test yang digunakan untuk mengetahui perbedaan hasil penilaian pembelajaran menggunakan aplikasi permainan edukatif Si Marbel pada nilai pre test dan nilai pos test. Uji $\mathrm{t}$ tes menggunakan SPSS 20 tertera pada Tabel 1:

Tabel 1. Hasil perhitungan t-test pre-tes dan pos-tes

\begin{tabular}{|c|c|c|c|}
\hline & Mean & $\mathrm{N}$ & $\begin{array}{l}\text { Standar } \\
\text { deviasi }\end{array}$ \\
\hline $\begin{array}{l}\text { Nilai } \\
\text { test }\end{array}$ & Pre 72,50 & 16 & 15,706 \\
\hline $\begin{array}{l}\text { Nilai } \\
\text { test }\end{array}$ & Pos 92,19 & 16 & 5,764 \\
\hline
\end{tabular}

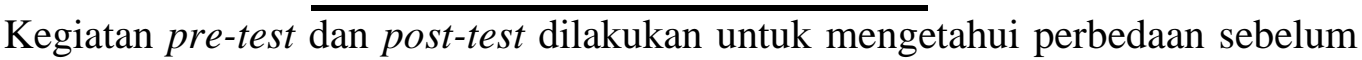
penggunaan dan sesudah penerapan aplikasi edukatif Si Marbel. Pelaksanaan pre-test dilakukan secara langsung di kelas, sedangkan pembelajaran atau penerapan aplikasi dan post-test dilaksanakan secara online. Sehubungan dengan pandemi virus Covid-19, maka pelaksanaan pembelajaran menurut surat edaran mendikbud no 4 tahun 2020 tertanggal 24 Maret 2020 dilaksanakan secara online dari rumah masing-masing peserta didik, aturan ini berisi bagaimana memprioritaskan kesehatan para peserta didik, guru dan seluruh waga sekolah. Prosedur menggunakan Si Marbel (Aplikasi Mari Belajar) dalam pembelajaran membuat link Si Marbel (Aplikasi Mari Belajar); mengirimkan lamat link tersebut ke group Whatshap kelas I-B; selanjutnya arahan diberikan melalui grup Whatsapp kepada orang tua peserta didik, baik dalam penerapanan aplikasi maupun dalam evaluasi pembelajaran (pre-tes).

Instrumen penelitian yang disiapkan oleh peneliti berupa kisi-kisi soal, soal, Rencana Pelaksanaan Pembelajaran (RPP), lembar penilaian Rencana Pelaksanaan Pembelajaran (RPP), lembar penilaian pretes dan postes. Penyusunan instrumen penilaian dimulai dengan membuat kisi-kisi soal, kemudian membuat soal, lalu soal diujicobakan dan di uji validitas dan reliabilitas, soal yang valid selanjutnya digunakan untuk melakukan penelitian. Kemudian menyusun Rencana Pelaksanaan Pembelajaran (RPP) menggunakan media aplikasi permainan edukatif Si Marbel. Selanjutnya hasil pre test dan post test diuji desktiptif, uji normalitas, dan uji t untuk menentukan efektifitas pengembangan permainan edukatif Aplikasi Mari Belajar (Si Marbel) dalam pembelajaran tematik kelas 1 MI Negeri Salatiga.

Impelementasi Si Marbel (Aplikasi Mari Belajar) dengan tahapan pretest secara langsung di kelas, pembelajaran, dan post-test dilakukan secara daring. Kelas daring ini 
dilaksanakan karena adanya masa pandemi korona atau yang dikenal dengan covid-19. Kelebihannya dari pelaksanaan pembelajaran online adalah peserta didik dan orang tua bisa mengenal pembelajaran dengan teknologi, adapun kekurangannya adalah kesulitan yang dialami ada 25 persen peserta didik dan orang tua terkendala dengan adanya pembelajaran dalam jaringan (daring) atau online. Solusi yang diambil peneliti atas kesulitan pembelajaran ini adalah dengan cara mendatangi rumah peserta didik yang mengalami kesulitan dan membimbing peserta didik melaksanakan pembelajaran (Andriani Ningsih, 2015).

Proses pembelajaran dilaksanakan pada tanggal 30-31 Maret 2020 yang melibatkan pendidik, peserta didik, orang tua peserta didik, dan peneliti. Sebelum memulai pembelajaran, peserta didik harus mengunduh Si Marbel (Aplikasi Mari Belajar) di https//gg.gg/MediaOnlineTemaPengalamanku. Selama proses ini, peserta didik dan orang tua dipandu dengan pesan-pesan Whatsapp. Pembelajaran dimulai dengan penjelasan penggunaan aplikasi dilanjutkan Tanya-jawab selama 70 menit. Pembelajaran ditutup dengan post-test pada hari kedua bagi yang belum menyelesaikan posttest bagi yang belum bisa mengunduh materi dipandu kembali dan didatangi oleh peneliti dan wali kelas dilaksanakan selama 70 menit.

Keberhasilan pembelajaran didukung banyak hal, dan perlu diterapkan pelatihan serta pembiasaan, penanaman karakter (Mustoip, 2018). Dalam pengembangan pembelajaran ada tiga pilar yang menentukan keberhasilan, yaitu kegiatan pembelajaran di kelas, kegiatan pembiasaan (habituasi) dan karakter atau pembiasaan rutin, spontan dan keteladanan (Tri Sukitman, 2016). Masa Pandemi covid 19, pembelajaran dengan melibatkan orang tua dengan pembelajaran jarak jauh adalah upaya yang tepat, karena ada pembelajaran di rumah dengan pendekatan ketaladanan. Pengembangan aplikasi permainan edukatif Si Marbel menggunakan Adobe Animate CC. Komponen penting bagi peserta didik dalam mempelajari materi adalah perangkat pembelajaran, maka perangkat pembelajaran harus disiapkan dengan baik (Muslim \& Supriatna, 2016).

Langkah-langkah pengembangan aplikasi permainan edukatif Si Marbel model ADDIE dilaksanakan dengan beberapa tahapan mulai dari analisis permasalahan, desain perancangan, dan pengembangan. Kebutuhan sekolah terhadap aplikasi permainan edukatif Si Marbel dengan analisis kebutuhan yang sesuai. Desain perancangan adalah berupa aplikasi permainan edukatif. Menentukan nama aplikasi yaitu "Si Marbel".

Sedangkan, kegiatan pelaksanaan pembelajaran menggunakan Si Marbel dilakukan sesuai dengan langkah-langkah desain aplikasi "Si Marbel" adalah:(a) membuat ide/gagasan, (b) menganalisa kebutuhan dan karakteristik peserta didik, (c) merumuskan tujuan, (d) menentukan kerangka isi bahan pelajaran, (e) menentukan jenis media, (f) menentukan treatmen dan partisipasi peserta didik, (g) membuat skets/story board, (h) pelaksanaan pembuatan media, (i) penyuntingan, (j) ujicoba, (k) melaksanakan kegiatan dan mengevaluasi. Langkah-langkah pengembangan secara terperinci pada development (pengembangan) di bawah ini.

Dalam pelaksanaan Pembelajaran, pendidik harus mampu mengembangkan kemampuan berfikir peserta didik dan memahami tujuan pembelajaran sebagai hakikat pembelajaran (Agustiningsih, 2010). Pengetahuan dan ketrampilan akademik dapat dikembangkan selama study sebagai kriteria tersebut untuk mengetahui perkembangan pengetahuan dan penilaian (Vronsky \& Vronsky, 2012). Pengembangan apresiasi peserta didik, pada hakikatnya mengembangkan aktifitas jiwa yang diharapkan tumbuh respon emosional dan intelektual, karena keberhasilan seseorang juga ditentuak oleh kecerdasan emosi tidak hanya intelektual (Suhartiningsih, 2012). 


\section{SIMPULAN}

Pengembangan aplikasi permainan edukatif sebagai media pembelajaran tematik dibutuhkan di MI Negeri Salatiga khususnya peserta didik kelas 1 pada tema 5 "Pengalamanku" yang meliputi mata pelajaran Bahasa Indonesia, SBdP, Pendidikan Kewarganegaraan, dan matematika. Materi yang dimasukkan ke dalam aplikasi adalah Mengenal Ungkapan Pujian, Bilangan Cacah, Pancasila, dan Elemen Musik. Aplikasi permainan edukatif Si Marbel dikembangkan menggunakan Adobe Animate CC. Setelah proses pengembangan, Si Marbel diuji kelayakannya oleh para ahli aplikasi dan ahli materi. Hasil penilaian pakar media masing-masing adalah 90 dan 93. Rata-rata adalah 91,5 yang menunjukkan bahwa pengembangan aplikasi pendidikan Si Marbel valid dan dapat diterapkan untuk pembelajaran di kelas 1 MI Negeri Salatiga. Uji efektifitas menunjukkan signifikansi (2-tailed) adalah 0,000 ( $\mathrm{p}<0,05)$. Hasil pre-test dan post-test menunjukkan perubahan yang signifikan. Statistik deskriptif dari nilai-nilai pre-test dan post-test menunjukkan bahwa skor post-test lebih baik, artinya bahwa ada perbedaan dalam hasil belajar sebelum dan sesudah belajar menggunakan aplikasi permainan edukatif Si Marbel. Dapat disimpulkan bahwa aplikasi permainan edukatif Si Marbel efektif digunakan dalam pembelajaran tematik tema 5 "Pengalamanku".

\section{REFERENSI}

Agustiningsih. (2010). Pengembangan Perangkat Pembelajaran Multimetode IPA SD Kelas V pada Pokok Bahasan Sistem Pernapasan Manusia. Jurnal Ilmu Pendidikan Sekolah Dasar, 1(1), 120-130.

Andriani Ningsih, P. (2015). Pengaruh Penggunaan Media Batang Cuisenaire terhadap Hasil Belajar Siswa pada Materi Penjumlahan Dan Pengurangan Bilangan Di Sekolah Dasar. Jurnal Penelitian Pendidikan Guru Sekolah Dasar, 03(02), 1912-1921.

Astini, B. N., -, N., Rachmayani, I., \& Suarta, I. N. (2017). Identifikasi Pemafaatan Alat Permaian Edukatif (Ape) Dalam Mengembangka Motorik Halus Anak Usia Dini. Jurnal Pendidikan Anak, 6(1), 31-40. https://doi.org/10.21831/jpa.v6i1.15678

Astini, B. N., Nurhasanah, \& Rahmayati, I. (2016). Al-Quran Dan Pemanfaatan Permainan Edukatif Pada Anak Usia Dini. Al-Afkar : Jurnal Keislaman \& Peradaban, 3(1), 99-124. https://doi.org/10.28944/afkar.v3i1.97

Eddia Copeland Solas, K. W. (2017). Instructor' s Use o f Student-Generated Annotated Concept Sketches in Formative Assessment in General Science. Journal of Turkish Science Education, 14(4), 144-161. https://doi.org/10.12973/tused.10217a

Huberman, M. dan. (2017). Analisis Data Kualitatif. Jakarta. UI Press.

Kuncahyono, K., \& Sudarmiatin, S. (2018). Pengembangan Multimedia Interaktif Pada Pembelajaran Tematik Indahnya Negeriku Untuk Siswa Kelas IV Sekolah Dasar. Ilmu Pendidikan: Jurnal Kajian Teori Dan Praktik Kependidikan, 3(2), 156-163.

Muazzomi, N. (2017). Pengembangan Alat Permainan Edukatif Pendidikan Anak Usia Dini Melalui Aplikasi Microsoft Powerpoint. Jurnal Ilmiah Universitas Batanghari Jambi, 17(1), 133-142. https://doi.org/10.33087/jiubj.v17i1.110 
Muslim, A. H., \& Supriatna. (2016). Pengembangan Perangkat Pembelajaran PKn Model Cooperative Tipe TGT Berbasis ATONG bagi Siswa Sekolah Dasar. Jurnal Pendidikan Sekolah Dasar, 2(2), 1-14.

Mustoip, S. (2018). Character Education Implementation for Students in Grade IV SDN 5 Sindangkasih Regency of Purwakarta West Java. Jurnal Pendidikan Dasar Dan Pembelajaran Volume, 8(2), 112-126. https://doi.org/10.25273/pe.v8i2.2739

Nugraheni, A. S., \& Siti Khanifah. (2016). Peran Kepala Madrasah sebagai Motivator dalam Meingkatkan Profesionalisme Guru. Jurnal Pendidikan Sekolah Dasar, 2(2), 15-23.

Panigrahi, M. R. (2014). School Effectiveness at Primary Level of Education in Relation to Classroom Teaching. International Journal of Instruction, 7(2), 5164.

Pétervári, J., Osman, M., \& Bhattacharya, J. (2016). The role of intuition in the generation and evaluation stages of creativity. Frontiers in Psychology, 7(SEP), 1-12. https://doi.org/10.3389/fpsyg.2016.01420

Suhartiningsih. (2012). Meningkatkan Kemampuan Mengapresiasi Bacaan Cerita Siswa Kelas VI Sekolah Dasar Melalui Pendekatan Area Isi. Jurnal Pendidikan Sekolah Dasar, 1(2).

Suparlan. (2014). Pendidikan IPTEK Transformatif. TERAMPIL: Jurnal Pendidikan Dan Pembelajaran Dasar, 2(2), 155-172.

Tri Sukitman. (2016). Internalisasi Pendidikan Nilai dalam Pembelajaran (Upaya menciptakan sumber daya manusia yang berkarakter). Jurnal Pendidikan Sekolah Dasar, 2(2), 85-96.

Unver, S. K. (2018). Views of Mathematics Student Teachers on Teacher Insights into the Teaching Process. International Journal of Instruction, 11(4), 689-700.

Vronsky, O., \& Vronsky, N. (2012). Graphical Competence as The Indicator of The Quality Level of Descriptive Geometry Studies. Journal of International Scientific Publication, 10(2), 202-363.

Wijayanti, R. (2014). Permainan Tradisional Sebagai Media Pengembangan Kemampuan Sosial Anak. Cakrawala Dini, 5(1), 51-56. https://doi.org/10.1109/SSD.2017.8166951 